\title{
High Catalytic Activity of Heteropolynuclear Cyanide Complexes Containing Cobalt and Platinum Ions: Visible-Light Driven Water Oxidation
}

Yusuke Yamada, Kohei Oyama, Rachel Gates and Shunichi Fukuzumi

\begin{tabular}{|c|c|}
\hline Citation & Angewandte Chemie International Edition, 54(19) : 5613-5617 \\
\hline Issue Date & $2015-5$ \\
\hline Type & Journal Article \\
\hline Textversion & author \\
\hline Rights & $\begin{array}{l}\text { This is the peer reviewed version of the following article: YAMADA, Y., OYAMA, K., } \\
\text { GATES, R., \& FUKUZUMI, S. Angewandte Chemie International Edition. Vol.54, } \\
\text { Issu.19, 5613-5617., which has been published in final form at } \\
\text { https://doi.org/10.1002/anie.201501116 . This article may be used for non-commercial } \\
\text { purposes in accordance with Wiley Terms and Conditions for Self-Archiving. } \\
\text { この論文は出版社版でありません。引用の際には出版社版をご確認ご利用ください。 }\end{array}$ \\
\hline DOI & Info:doi/10.1002/anie.201501116 \\
\hline
\end{tabular}

Self-Archiving by Author(s)

Placed on: Osaka City University Repository

YAMADA, Y., OYAMA, K., GATES, R., \& FUKUZUMI, S. (2015). High Catalytic Activity of Heteropolynuclear Cyanide Complexes Containing Cobalt and Platinum Ions: Visible-Light Driven Water Oxidation. Angewandte Chemie International Edition. $54, \quad 5613-5617$. 


\title{
High Catalytic Activity of Heteropolynuclear Cyanide Complexes Con- taining Co and Pt Ions for Visible-Light Driven Water Oxidation**
}

\author{
Yusuke Yamada,* Kohei Oyama, Rachel Gates, and Shunichi Fukuzumi*
}

\begin{abstract}
Nearly stoichiometric amount of $\mathrm{O}_{2}$ evolution was observed by visible-light irradiation of an aqueous solution containing $\left[\mathrm{Ru}^{I I}\left(2,2^{\prime} \text {-bipyridine }\right)_{3}\right]^{2+}, \mathrm{Na}_{2} \mathrm{~S}_{2} \mathrm{O}_{8}$ and a heteropolynuclear cyanide complex containing Co and Pt as a photosensitizer, a sacrificial electron acceptor and a water oxidation catalyst, respectively. The heteropolynuclear cyanide complexes exhibited higher catalytic activity than a polynuclear cyanide complex solely containing either Co or Pt ions. The origin of synergistic effect between Co and Pt is discussed in relation to electronic and local atomic structures of the complexes.
\end{abstract}

Increasing demand by human beings for energy encourages researchers to realize artificial photosynthesis, in which high-energy compounds are produced from water as an electron donor, utilizing solar energy. ${ }^{[1-3]} \mathrm{A}$ bottleneck to realize the artificial photosynthesis is low activity of water oxidation catalysts. ${ }^{[4-5]}$ A wide variety of homogeneous and heterogeneous catalysts have been examined for the water oxidation. ${ }^{[6,7]}$ Metal complexes often used as homogeneous catalysts are advantageous for designing the active species, however their low stability causes a problem about truly active species. ${ }^{[8]}$ Metal oxides have also been extensively studied in heterogeneous systems as robust water oxidation catalysts, although their catalytically active species remain equivocal in multiple component systems. ${ }^{[9]}$ Recently, metal organic frameworks (MOFs) emerged as potential candidates possessing both designable structures in atomic level and robustness under harsh reaction conditions. ${ }^{[10]}$

Heteropolynuclear cyanide complexes are the simplest class of MOFs. In general, heteropolynuclear cyanide complexes take a cubic structure as far as contained metal ions allow octahedral coordination. ${ }^{[11]}$ Both $\mathrm{C}$ and $\mathrm{N}$ atoms of cyanide interact with metal ions, however, the $\mathrm{C}$ atom tends to coordinate to a metal ion more firmly. When the number of N-bound metal ions is larger than that of C-

[*] Assoc. Prof. Dr. Yusuke Yamada, Kohei Oyama and Prof. Dr. Shunichi Fukuzumi

Department of Material and Life Science

Graduate School of Engineering, Osaka University

2-1 Yamada-oka, Suita, Osaka 565-0871 (Japan)

Fax: (+) 81-6879-7370

E-mail: yamada@chem.eng.osaka-u.ac.jp

fukuzumi@chem.eng.osaka-u.ac.jp

http://www-etchem.mls.eng.osaka-u.ac.jp/

Prof. Dr. Shunichi Fukuzumi

Department of Bioinspired Science

Ewha Womans University, Seoul 120-750 (Korea)

Rachel Gates

California Institute of Technology

1200 East California Boulevard, Pasadena, California, 91125 (USA)

[**] This work was supported by an ALCA project from JST (to S.F.) and a Grants-in-Aid (Nos. 24350069 and 25600025 to Y.Y.) from the Ministry of Education, Culture, Sports, Science and Technology, Japan.

Supporting information for this article is available on the WWW under http://www.angewandte.org or from the author bound metal ions, the N-bound metal ions need external ligands such as an aqua ligand to fulfill octahedral coordination. In such a case, the aqua ligands can be liberated from the N-bound metal ions in a reaction solution to provide substrate-binding sites. ${ }^{[12]}$ The number of external ligands can be controlled by considering charge compensation in a heteropolynuclear complex. ${ }^{[12]}$ Additionally, the character of the N-bound metal ion can be influenced by the Cbound metal ion through $\mathrm{p} \pi-\mathrm{d} \pi$ interaction among a cyanide ligand and the metal ions. ${ }^{[13]}$ Thus, heteropolynuclear cyanide complexes can be designable heterogeneous catalysts for water oxidation.

We report herein visible-light driven water oxidation catalysis of heteropolynuclear cyanide complexes containing both Co and Pt ions, which are superior to polynuclear cyanide complexes solely containing either Co or Pt ions. The heteropolynuclear complexes contain $\mathrm{Co}^{\mathrm{III}}$ and $\mathrm{Pt}^{\mathrm{IV}}$ ions as $\mathrm{C}$-bound metal ions and $\mathrm{Co}^{\mathrm{II}}$ ions as $\mathrm{N}$ bound metal ions. The higher oxidation state of $\mathrm{Pt}^{\mathrm{IV}}$ than that of $\mathrm{Co}^{\mathrm{III}}$ can be expected to enhance the oxidation ability of $\mathrm{Co}^{\mathrm{II}}$ ions. When heteropolynuclear cyanide complexes contain $\mathrm{Pt}^{\mathrm{II}}$ ions instead of $\mathrm{Pt}^{\mathrm{IV}}$ ions, the number of defect sites increases in the framework, resulting in increasing the number of active sites accessible by a substrate molecule. Both electronic and structural effects are examined for a series of cyanide complexes by changing content of Pt ion.

The catalysis of the heteropolynuclear cyanide complexes for visible-light driven water oxidation was examined in a reaction solution containing $\left(\left[\mathrm{Ru}(\mathrm{bpy})_{3}\right]^{2+}\right.$ : bpy $=2,2$ '-bipyridine) and $\mathrm{S}_{2} \mathrm{O}_{8}{ }^{2-}$ as a photosensitizer and a sacrificial electron acceptor, respectively. The overall catalytic cycle is shown in Scheme 1, where photoexcited $\left[\mathrm{Ru}(\mathrm{bpy})_{3}\right]^{2+}$ initiates the reaction by reducing $\mathrm{Na}_{2} \mathrm{~S}_{2} \mathrm{O}_{8}$, and $\left[\mathrm{Ru}(\mathrm{bpy})_{3}\right]^{3+}$ thus formed oxidizes a heteropolynuclear cyanide complex which then oxidizes water for $\mathrm{O}_{2}$ evolution.

Scheme 1. Overall Catalytic Cycle of Visible-light Driven Water Oxidation

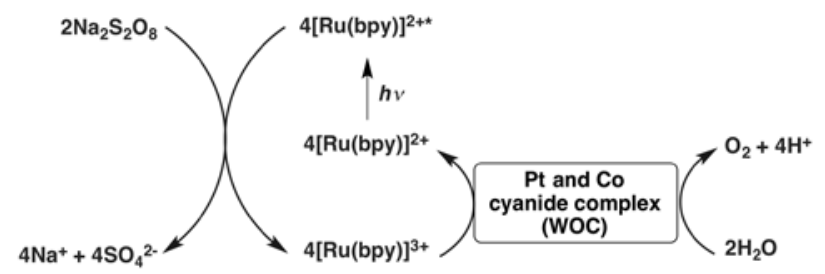

A series of the heteropolynuclear cyanide complexes containing $\mathrm{Pt}^{\mathrm{IV}}$ ions, $\left[\mathrm{Co}^{\mathrm{II}}\left(\mathrm{H}_{2} \mathrm{O}\right)_{\mathrm{m}}\right]_{\mathrm{n}}\left[\left(\mathrm{Co}^{\mathrm{III}}{ }_{1-\mathrm{x}} \mathrm{Pt}^{\mathrm{IV}}{ }_{\mathrm{x}}\right)(\mathrm{CN})_{6}\right]$, were prepared by mixing an aqueous solution containing both $\mathrm{K}_{3}\left[\mathrm{Co}^{\mathrm{III}}(\mathrm{CN})_{6}\right]$ and $\mathrm{K}_{2}\left[\mathrm{Pt}^{\mathrm{IV}}(\mathrm{CN})_{6}\right]$ with various Co/Pt ratios ranging from 1:0 to $0: 1$ and an aqueous solution containing an excess amount of $\mathrm{Co}\left(\mathrm{NO}_{3}\right)_{2}$. The formed crystalline powder was collected by filtration. The contents of $\mathrm{Co}$ and Pt ions of each powder were determined by X-ray fluorescence measurements. The number of $\mathrm{Co}^{\mathrm{II}}$ ions in a unit cell decreases by increasing the number of $\mathrm{Pt}^{\mathrm{IV}}$ ions in a unit cell $(\mathrm{n}=1.5-$ $0.5 \mathrm{x}$ ). Also, the number of water molecules coordinating to $\mathrm{Co}^{\mathrm{II}}$ ions decreases from 2 to 0 by increasing the content of $\mathrm{Pt}^{\mathrm{IV}}$ ions $(\mathrm{m}=$ $3 \times(1-x) / n)$ (Note in page S2). No peak from $\mathrm{K}^{+}$ions was observed 
for all samples, indicating that the content of contaminated $\mathrm{K}^{+}$ions was lower than $0.12 \%$. Incorporation of $\mathrm{Co}^{\mathrm{II}}$ ions in the framework was also confirmed by the higher wavenumber shift of the CN stretching bands $[r(\mathrm{CN})]$ in IR spectra (Figure S1). Powder X-ray diffraction patterns for the heteropolynuclear cyanide complexes with contents of $\mathrm{Pt}^{\mathrm{IV}}$ ion ranging from 0 to 1 shown in Figure 1a were assignable to the cubic structure (Figure $1 \mathrm{~b}$ ), which is often called as Prussian blue analogue structure. The gradual decrease of the diffraction peaks in $2 \theta$ angle in accordance with increase in the content of $\mathrm{Pt}^{\mathrm{IV}}$ ions reflects the expansion of a unit cell due to the larger ionic radii of a $\mathrm{Pt}^{\mathrm{IV}}$ ion $(0.77 \AA)$ than that of a $\mathrm{Co}^{\mathrm{III}}$ ion $(0.69$ $\AA) .{ }^{[14]}$ Microporous structures of the series of complexes were also evidenced by the Brunauer-Emmett-Teller (BET) surface areas higher than $400 \mathrm{~m}^{2} \mathrm{~g}^{-1}$ (Figure S2).
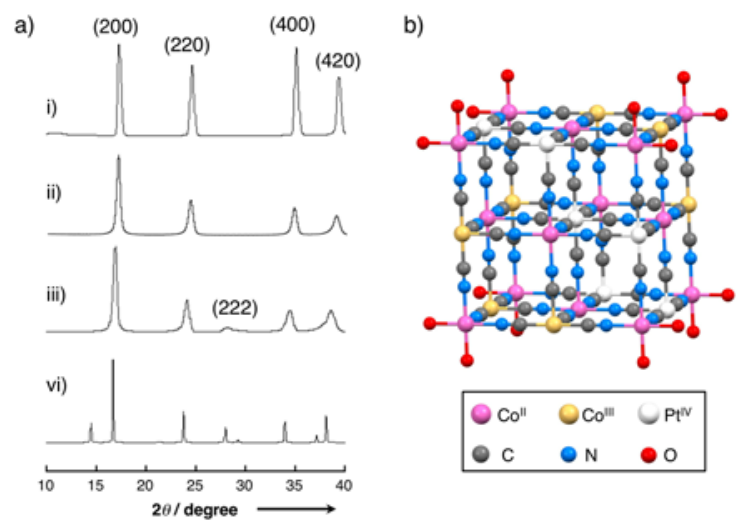

Figure 1. a) Powder $\mathrm{X}$-ray diffraction patterns of a series of heteropolynuclear cyanide complexes, $\left.\left[\mathrm{Co}^{\prime \prime}\left(\mathrm{H}_{2} \mathrm{O}\right)_{\mathrm{m}}\right]_{n}\left[\mathrm{Co}^{\prime \prime \prime}{ }_{1-\mathrm{xPt}}{ }^{\mathrm{IV}} \times(\mathrm{CN})_{6}\right] . \mathrm{x}=\mathrm{i}\right)$ 0 , ii) 0.15 , iii) 0.43 and iv) 1. b) A schematic drawing of [Co" $\left.\left(\mathrm{H}_{2} \mathrm{O}\right)_{m}\right]_{n}\left[\left(\mathrm{Co}^{\prime \prime \prime}{ }_{1-\mathrm{x}} \mathrm{Pt}^{\mathrm{IV}}{ }_{\mathrm{x}}\right)(\mathrm{CN})_{6}\right]$. Ions are color coded: Co" (pink), $\mathrm{N}$ (blue); C (black); O (red); Co ${ }^{\text {III }}$ (yellow) and $\mathrm{Pt}^{\mathrm{IV}}$ (white). Hydrogen atoms of water molecules are omitted.

Replacement of $\mathrm{Co}^{\mathrm{III}}$ ions in $\left[\mathrm{Co}^{\mathrm{II}}\left(\mathrm{H}_{2} \mathrm{O}\right)_{2}\right]_{1.5}\left[\mathrm{Co}^{\mathrm{III}}(\mathrm{CN})_{6}\right]$ by $\mathrm{Pt}^{\mathrm{IV}}$ ions enhances the oxidation ability of $\mathrm{Co}^{\mathrm{II}}$ ions. The oxidation potential of $\mathrm{Co}^{\mathrm{II}}$ ions in $\left[\mathrm{Co}^{\mathrm{II}}\left(\mathrm{H}_{2} \mathrm{O}\right)_{\mathrm{m}}\right]_{\mathrm{n}}\left[\left(\mathrm{Co}^{\mathrm{III}}{ }_{1-\mathrm{x}} \mathrm{Pt}^{\mathrm{IV}}{ }_{\mathrm{x}}\right)(\mathrm{CN})_{6}\right]$ were examined by differential pulse voltammetry (DPV) in an acetonitrile suspension. The oxidation peak originated from $\mathrm{Co}^{\mathrm{II}}$ to $\mathrm{Co}^{\mathrm{III}}$ in $\left[\mathrm{Co}{ }^{\mathrm{II}}\left(\mathrm{H}_{2} \mathrm{O}\right)_{2}\right]_{1.5}\left[\mathrm{Co}^{\mathrm{III}}(\mathrm{CN})_{6}\right]\left(0.67 \mathrm{~V}\right.$ vs. $\left.\mathrm{Ag} / \mathrm{Ag}^{+}\right)$was observed in an anodic sweep. The oxidation peak of $\mathrm{Co}^{\mathrm{II}}$ to $\mathrm{Co}^{\mathrm{III}}$ was gradually shifted in the positive direction to $0.94 \mathrm{~V}$ by increasing the content of $\mathrm{Pt}^{\mathrm{IV}}$ ions to 1.0 (Figure 2). The positive shift with increasing the content of $\mathrm{Pt}^{\mathrm{IV}}$ ions evidences the electronic interaction between $\mathrm{Pt}^{\mathrm{IV}}$ and $\mathrm{Co}^{\mathrm{II}}$ ions. The electronic interaction between $\mathrm{Co}^{\mathrm{II}}$ and $\mathrm{Pt}^{\mathrm{IV}}$ ions also depends on the content of $\mathrm{Pt}^{\mathrm{IV}}$ ion, evidenced by the shift of absorption maxima originating from the metal-to-metal charge transfer band appearing in the near IR region (Figure S3). The absorption band appeared at around $1165 \mathrm{~nm}$ for $\left[\mathrm{Co}^{\mathrm{II}}\left(\mathrm{H}_{2} \mathrm{O}\right)_{2}\right]_{1.5}\left[\mathrm{Co}^{\mathrm{III}}(\mathrm{CN})_{6}\right](\mathrm{x}=0)$ and was gradually shifted to 1126 $\mathrm{nm}$ by increasing the content of $\mathrm{Pt}^{\mathrm{IV}}$ ions in $\left[\mathrm{Co}^{\mathrm{II}}\left(\mathrm{H}_{2} \mathrm{O}\right)_{1.33}\right]_{1.29}\left[\left(\mathrm{Co}^{\mathrm{III}}{ }_{0.57} \mathrm{Pt}^{\mathrm{IV}}{ }_{0.43}\right)(\mathrm{CN})_{6}\right](\mathrm{x}=0.43)$. The near IR bands were assigned to metal-to-metal charge transfer from $e_{\mathrm{g}}$ orbitals of $\mathrm{Co}^{\mathrm{II}}$ (high spin) to $e_{\mathrm{g}}$ orbitals of $\mathrm{Co}^{\mathrm{III}}$ or $\mathrm{Pt}^{\mathrm{IV}}$ (low spin). ${ }^{[15]}$ The positive shift of the oxidation potential of $\mathrm{Co}^{\mathrm{II}}$ observed in DPV suggests the energy level of the $e_{\mathrm{g}}$ orbital of $\mathrm{Co}^{\text {II }}$ ions decreases.

Photocatalytic water oxidation was performed by photoirradiation $(\lambda>420 \mathrm{~nm})$ of a phosphate buffer $(2.0 \mathrm{~mL}, 50 \mathrm{mM}, \mathrm{pH} 8.0)$ containing $\left[\mathrm{Ru}(\mathrm{bpy})_{3}\right]^{2+}(1.0 \mathrm{mM}), \quad \mathrm{Na}_{2} \mathrm{~S}_{2} \mathrm{O}_{8}\left(\begin{array}{llll}5.0 & \mathrm{mM}\end{array}\right)$ and $\left[\mathrm{Co}^{\mathrm{II}}\left(\mathrm{H}_{2} \mathrm{O}\right)_{\mathrm{m}}\right]_{\mathrm{n}}\left[\left(\mathrm{Co}^{\mathrm{III}}{ }_{1-\mathrm{x}} \mathrm{Pt}^{\mathrm{IV}}{ }_{\mathrm{x}}\right)(\mathrm{CN})_{6}\right](80 \mu \mathrm{g})$. Time courses of $\mathrm{O}_{2}$

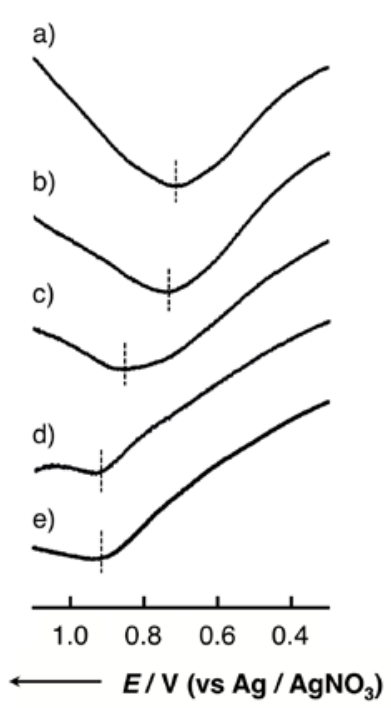

Figure 2. Differential pulse voltammetry of a series of heteropolynuclear cyanide complexes, [Co $\left.\left.{ }^{\prime \prime}\left(\mathrm{H}_{2} \mathrm{O}\right)_{m}\right]_{n}\left[\left(\mathrm{Co}^{\mathrm{II \prime}}{ }_{1-\mathrm{x}} \mathrm{Pt}^{\mathrm{lv}} \mathrm{x}\right)(\mathrm{CN})_{6}\right] . \mathrm{x}=\mathrm{a}\right) 0$; b) 0.15 ; c) 0.43 ; d) 0.69 and e) 1 . The measurements were performed in an acetonitrile $(2.0 \mathrm{~mL})$ suspension of $\left[\mathrm{Co}^{\prime \prime}\left(\mathrm{H}_{2} \mathrm{O}\right)_{\mathrm{m}}\right]_{\mathrm{n}}\left[\left(\mathrm{Co}^{\mathrm{III}}{ }_{1-\mathrm{xPt}} \mathrm{Pt}_{\mathrm{x}}^{\mathrm{lv}}\right)(\mathrm{CN})_{6}\right]$ (10 $\mu \mathrm{mol})$ using a glassy carbon electrode, a Pt wire and an $\mathrm{Ag} / \mathrm{AgNO}_{3}$ electrode as the working electrode, counter electrode and reference electrode, respectively.
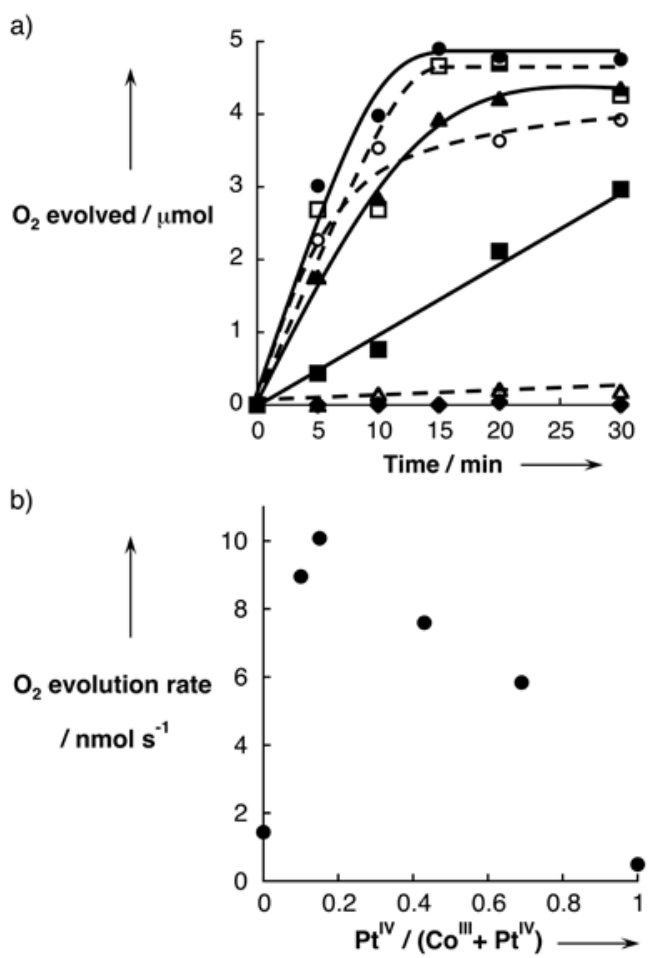

Figure 3. a) Time courses of $\mathrm{O}_{2}$ evolution by visible-light irradiation ( $\lambda$ $>420 \mathrm{~nm})$ of a phosphate buffer $(2.0 \mathrm{~mL}, 50 \mathrm{mM}, \mathrm{pH}$ 8.0) containing $\left[\mathrm{Ru}(\mathrm{bpy})_{3}\right]^{2+}(1.0 \mathrm{mM}), \mathrm{Na}_{2} \mathrm{~S}_{2} \mathrm{O}_{8}(5.0 \mathrm{mM})$ and a heteropolynuclear

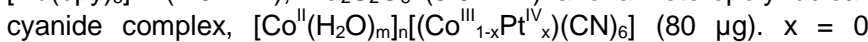
(closed square); 0.10 (open square); 0.15 (closed circle); 0.43 (open circle); 0.69 (closed triangle) and 1 (open triangle). Time course of $\mathrm{O}_{2}$ evolution under dark conditions using the complex with $\mathrm{x}=0.15$ (open diamond). b) Initial $\mathrm{O}_{2}$ evolution rates $(<5 \mathrm{~min}$ ) depending on the content of $\mathrm{Pt}^{\mathrm{IV}}$ ion in $\left[\mathrm{Co}^{\prime \prime}\left(\mathrm{H}_{2} \mathrm{O}\right)_{m}\right]_{n}\left[\left(\mathrm{Co}^{\prime \prime \prime}{ }_{1-\mathrm{x}} \mathrm{Pt}^{\mathrm{IV}} \times\right)(\mathrm{CN})_{6}\right]$. 
evolution are indicated in Figure 3a. No $\mathrm{O}_{2}$ evolution was confirmed under dark conditions before photoirradiation. An insignificant amount of $\mathrm{O}_{2}$ evolution was observed for the reaction solution containing $\mathrm{Co}^{\mathrm{II}}\left[\mathrm{Pt}^{\mathrm{IV}}(\mathrm{CN})_{6}\right]$. In contrast, a significant amount of $\mathrm{O}_{2}$ evolution was observed for the reaction solution containing $\left[\mathrm{Co}^{\mathrm{II}}\left(\mathrm{H}_{2} \mathrm{O}\right)_{2}\right]_{1.5}\left[\mathrm{Co}^{\mathrm{III}}(\mathrm{CN})_{6}\right]$, where the $\mathrm{O}_{2}$ yield (based on the amount of $\mathrm{Na}_{2} \mathrm{~S}_{2} \mathrm{O}_{8}$ ) reached $\sim 60 \%$ after photoirradiation for $30 \mathrm{~min}$. The $\mathrm{O}_{2}$ yields were further increased to more than $80 \%$ by employing $\left[\mathrm{Co}^{\mathrm{II}}\left(\mathrm{H}_{2} \mathrm{O}\right)_{\mathrm{m}}\right]_{\mathrm{n}}\left[\left(\mathrm{Co}^{\mathrm{III}}{ }_{1-\mathrm{x}} \mathrm{Pt}^{\mathrm{IV}}{ }_{\mathrm{x}}\right)(\mathrm{CN})_{6}\right](\mathrm{x}=0.15,0.43$ and 0.69$)$ as WOCs. Especially, a nearly stoichiometric amount of $\mathrm{O}_{2}(>98 \%)$ was obtained for the reaction system containing $\left[\mathrm{Co}^{\mathrm{II}}\left(\mathrm{H}_{2} \mathrm{O}\right)_{1.79}\right]_{1.42}\left[\left(\mathrm{Co}^{\mathrm{III}}{ }_{0.85} \mathrm{Pt}^{\mathrm{IV}}{ }_{0.15}\right)(\mathrm{CN})_{6}\right](\mathrm{x}=0.15)$. The initial $\mathrm{O}_{2}$ evolution rates $(<5 \mathrm{~min})$ were plotted against the content of $\mathrm{Pt}^{\mathrm{IV}}$ ions in $\left[\mathrm{Co}^{\mathrm{II}}\left(\mathrm{H}_{2} \mathrm{O}\right)_{\mathrm{m}}\right]_{\mathrm{n}}\left[\left(\mathrm{Co}^{\mathrm{III}}{ }_{1-\mathrm{x}} \mathrm{Pt}^{\mathrm{IV}}{ }_{\mathrm{x}}\right)(\mathrm{CN})_{6}\right]$ (Figure $3 \mathrm{~b}$ ). The fastest $\mathrm{O}_{2}$ evolution was observed for $\left[\mathrm{Co}^{\mathrm{II}}\left(\mathrm{H}_{2} \mathrm{O}\right)_{1.79}\right]_{1.42}\left[\left(\mathrm{Co}^{\mathrm{III}}{ }_{0.85} \mathrm{Pt}^{\mathrm{IV}}{ }_{0.15}\right)(\mathrm{CN})_{6}\right]$ where the initial $\mathrm{O}_{2^{-}}$ evolution rate exceeds $10 \mathrm{nmol} \mathrm{s}{ }^{-1}$, which is comparable to that reported for the reaction system using $\mathrm{IrO}_{2}$ nanoparticles, which are known as one of the most active heterogeneous catalysts for the photocatalytic water oxidation, under the condition of $\mathrm{pH} 5$. $^{[16]}$

The $\mathrm{Co}^{\mathrm{III}}$ and $\mathrm{Pt}^{\mathrm{IV}}$ ions are coordinatively saturated, thus, Nbound $\mathrm{Co}^{\mathrm{II}}$ ions can act as active sites by liberating coordinating $\mathrm{H}_{2} \mathrm{O}$ molecules. The number of the $\mathrm{H}_{2} \mathrm{O}$ molecules decreases in proportion to the content of $\mathrm{Pt}^{\mathrm{IV}}$ ions due to charge compensation. On the other hand, the oxidation ability of $\mathrm{Co}^{\mathrm{II}}$ ions is more enhanced in the presence of $\mathrm{Pt}^{\mathrm{IV}}$ ions at higher contents by electronic interaction. The lowest activity of $\mathrm{Co}^{\mathrm{II}}\left[\mathrm{Pt}^{\mathrm{IV}}(\mathrm{CN})_{6}\right]$ in the $\mathrm{O}_{2}$ evolution rate suggested that the presence of labile coordination sites on $\mathrm{Co}^{\mathrm{II}}$ ion is as crucial as oxidation ability.

The robustness of the $\left[\mathrm{Co}^{\mathrm{II}}\left(\mathrm{H}_{2} \mathrm{O}\right)_{1.79}\right]_{1.42}\left[\left(\mathrm{Co}^{\mathrm{III}}{ }_{0.85} \mathrm{Pt}^{\mathrm{IV}}{ }_{0.15}\right)(\mathrm{CN})_{6}\right]$ was confirmed by the repetitive addition of an aliquot $(100 \mu \mathrm{L})$ of $\mathrm{Na}_{2} \mathrm{~S}_{2} \mathrm{O}_{8}$ to the reaction solution after ceasing $\mathrm{O}_{2}$ evolution. $\mathrm{O}_{2}$ yields higher than $90 \%$ were attained up to $3^{\text {rd }}$ run (Figure 4 ). The used catalyst was collected by centrifugation and used for IR spectrum and powder X-ray diffraction measurements. The IR spectrum measurements of the used sample showed no changes in peak positions and relative intensities of the two $r(\mathrm{CN})$ peaks at 2236 and $2175 \mathrm{~cm}^{-1}$ from those of the fresh sample (Figure S4). $\left[\mathrm{Co}^{\mathrm{II}}\left(\mathrm{H}_{2} \mathrm{O}\right)_{2}\right]_{1.5}\left[\mathrm{Co}^{\mathrm{III}}(\mathrm{CN})_{6}\right]$ has been reported to lose the catalytic activity for water oxidation by binding of bipyridine as evidenced by IR and Raman spectroscopy. ${ }^{[10 b]}$ Adsorption of $\left[\mathrm{Ru}(\mathrm{bpy})_{3}\right]^{2+}$ or bpy on the $\left[\mathrm{Co}^{\mathrm{II}}\left(\mathrm{H}_{2} \mathrm{O}\right)_{1.79}\right]_{1.42}\left[\left(\mathrm{Co}^{\mathrm{III}}{ }_{0.85} \mathrm{Pt}^{\mathrm{IV}}{ }_{0.15}\right)(\mathrm{CN})_{6}\right]$ after the

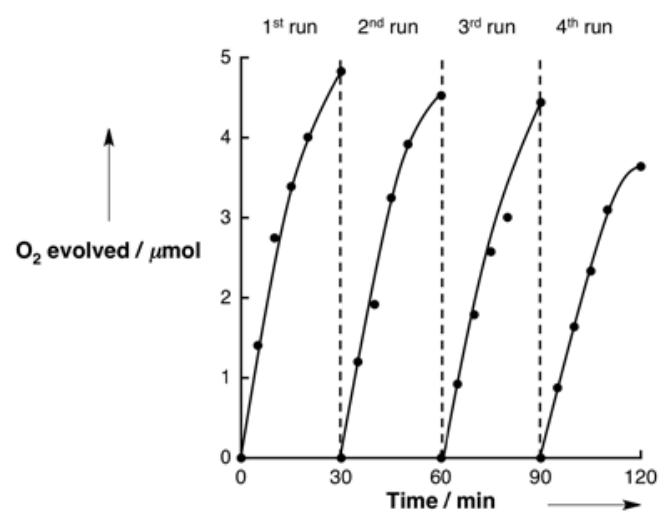

Figure 4. Time courses of $\mathrm{O}_{2}$ evolution by visible-light irradiation $(\lambda>$ $420 \mathrm{~nm})$ of a phosphate buffer $(2.0 \mathrm{~mL}, 50 \mathrm{mM}, \mathrm{pH} 8.0)$ containing $\left[\mathrm{Ru}(\mathrm{bpy})_{3}\right]^{2+} \quad(1.0 \quad \mathrm{mM}), \quad \mathrm{Na}_{2} \mathrm{~S}_{2} \mathrm{O}_{8} \quad\left(\begin{array}{lll}5.0 & \mathrm{mM}) & \text { and }\end{array}\right.$ $\left[\mathrm{Co}\left(\mathrm{H}_{2} \mathrm{O}\right)_{1.79}\right]_{1.42}\left[\left(\mathrm{Co}_{0.85} \mathrm{Pt}_{0.15}\right)(\mathrm{CN})_{6}\right](800 \mu \mathrm{g})$. A small portion of a concentrated $\mathrm{Na}_{2} \mathrm{~S}_{2} \mathrm{O}_{3}$ solution was added to the reaction solution to make a concentration of $\mathrm{Na}_{2} \mathrm{~S}_{2} \mathrm{O}_{8} 5.0 \mathrm{mM}$ after $\mathrm{O}_{2}$ evolution ceased. photocatalytic $\mathrm{O}_{2}$ evolution was also confirmed by the IR spectroscopy, however, deceleration effect of the adsorbent was limited. The XRD peaks of the used sample also contained all the peaks observed for the fresh sample (Figure S5). These results assure the robustness of the $\left[\mathrm{Co}^{\mathrm{II}}\left(\mathrm{H}_{2} \mathrm{O}\right)_{1.79}\right]_{1.42}\left[\left(\mathrm{Co}^{\mathrm{III}}{ }_{0.85} \mathrm{Pt}^{\mathrm{IV}}{ }_{0.15}\right)(\mathrm{CN})_{6}\right]$.

Effect of structural modification of the frameworks was confirmed by investigating the catalysis of $\left[\mathrm{Co}^{\mathrm{II}}\left(\mathrm{H}_{2} \mathrm{O}\right)_{2}\right]_{\mathrm{n}},\left[\left\{\mathrm{Co}^{\mathrm{III}}(\mathrm{CN})_{6}\right\}_{1}\right.$. $\left.{ }_{\mathrm{x}}\left\{\mathrm{Pt}^{\mathrm{II}}(\mathrm{CN})_{4}\right\}_{\mathrm{x}}\right]\left(\mathrm{n}^{\prime}=1.5-0.5 \mathrm{x}\right)$, which contains $\mathrm{Pt}^{\mathrm{II}}$ ions with a square planar coordination structure instead of $\mathrm{Pt}^{\mathrm{IV}}$ ions with an octahedral structure. The $\mathrm{Co}^{\mathrm{II}}$ ions in the complexes possess two $\mathrm{H}_{2} \mathrm{O}$ molecules as external ligands independent of content of $\mathrm{Pt}^{\mathrm{II}}$ ions (Note in page S3). When no $\mathrm{Co}^{\mathrm{III}}$ ion was included in a complex, the powder X-ray diffraction pattern indicated that the complex has a planar structure, not a cubic structure. However, complexes containing both $\mathrm{Co}^{\mathrm{III}}$ and $\mathrm{Pt}^{\mathrm{II}}$ ions provided the diffraction patterns indicating the cubic structure which is isostructural to Prussian blue (Figure $5 \mathrm{a}$ ). Also, $\mathrm{N}_{2}$ adsorption desorption isotherm indicated the presence of micropores with high BET surface area (Figure S2b). A schematic drawing of a typical structure of $\left[\mathrm{Co}^{\mathrm{II}}\left(\mathrm{H}_{2} \mathrm{O}\right)_{2}\right]_{\mathrm{n}^{\prime}}\left[\left\{\mathrm{Co}^{\mathrm{III}}(\mathrm{CN})_{6}\right\}_{1-\mathrm{x}}\left\{\mathrm{Pt}^{\mathrm{II}}(\mathrm{CN})_{4}\right\}_{\mathrm{x}}\right]$ is depicted in Figure $5 \mathrm{~b}$.

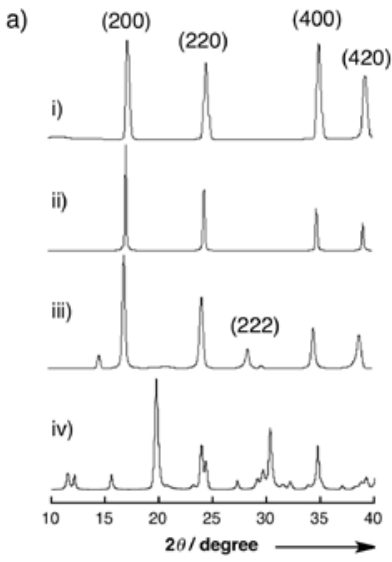

b)

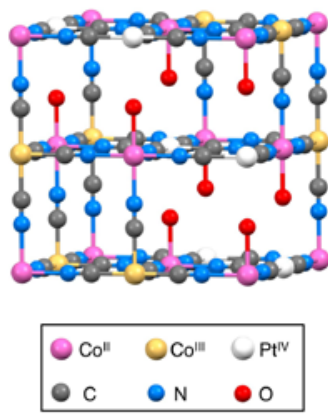

Figure 5. a) Powder X-ray diffraction patterns of a series of heteropolynuclear cyanide complexes, $\left[\mathrm{Co}^{\prime \prime}\left(\mathrm{H}_{2} \mathrm{O}\right)_{2}\right]_{n^{\prime}},\left[\left\{\mathrm{Co}^{\prime \prime \prime}(\mathrm{CN})_{6}\right\}_{1}\right.$ $\left.{ }_{x}\left\{\mathrm{Pt}^{\prime \prime}(\mathrm{CN})_{4}\right\}_{x}\right] . x=$ i) 0 , ii) 0.37 , iii) 0.60 and iv) 1. b) A schematic drawing of $\left[\mathrm{Co}^{\prime \prime}\left(\mathrm{H}_{2} \mathrm{O}\right)_{2}\right]_{n^{\prime}}\left[\left\{\mathrm{Co}^{\prime \prime \prime}(\mathrm{CN})_{6}\right\}_{1-x}\left\{\mathrm{Pt}^{\prime \prime}(\mathrm{CN})_{4}\right\}_{x}\right]$. Ions are color-coded: $\mathrm{CO}^{\text {II }}$ (pink), N (blue); C (black); O (red); Co ${ }^{\text {III }}$ (yellow); $\mathrm{Pt}^{\mathrm{IV}}$ (white). Hydrogen atoms of water molecules are omitted.

Photocatalytic water oxidation was performed by photoirradiation $(\lambda>420 \mathrm{~nm})$ of a phosphate buffer $(2.0 \mathrm{~mL}, 50 \mathrm{mM}$, pH 8.0$)$ containing $\left[\mathrm{Ru}(\mathrm{bpy})_{3}\right]^{2+}(1.0 \mathrm{mM}), \mathrm{Na}_{2} \mathrm{~S}_{2} \mathrm{O}_{8}\left(\begin{array}{lll}5.0 & \mathrm{mM}\end{array}\right)$ and $\left[\mathrm{Co}^{\mathrm{II}}\left(\mathrm{H}_{2} \mathrm{O}\right)_{2}\right]_{\mathrm{n}},\left[\left\{\mathrm{Co}^{\mathrm{III}}(\mathrm{CN})_{6}\right\}_{1-\mathrm{x}}\left\{\mathrm{Pt}^{\mathrm{II}}(\mathrm{CN})_{4}\right\}_{\mathrm{x}}\right](80 \mu \mathrm{g})$ with various contents of $\mathrm{Pt}^{\mathrm{II}}$ ion (Figure 6). The initial $\mathrm{O}_{2}$ evolution rate $(5 \mathrm{~min})$ of $\left.\left[\mathrm{Co}^{\mathrm{II}}\left(\mathrm{H}_{2} \mathrm{O}\right)_{2}\right]\left[\mathrm{Pt}^{\mathrm{II}}(\mathrm{CN})_{4}\right](6.0 \mathrm{nmol} \mathrm{s})^{-1}\right)$ was much higher than that of $\mathrm{Co}^{\mathrm{II}}\left[\mathrm{Pt}^{\mathrm{IV}}(\mathrm{CN})_{6}\right]\left(0.50 \mathrm{nmol} \mathrm{s}{ }^{-1}\right)$, resulting from the presence of water molecules coordinating to $\mathrm{Co}^{\mathrm{II}}$ ions. The initial $\mathrm{O}_{2}$ evolution rates increased by decreasing the content of $\mathrm{Pt}^{\mathrm{II}}$ ions up to 0.37 , where the initial $\mathrm{O}_{2}$ evolution rate exceeded $9.9 \mathrm{nmol} \mathrm{s}^{-1}$ with a nearly stoichiometric amount of $\mathrm{O}_{2}$ evolution. An apparent quantum yield determined by using monochromatized light with $450 \mathrm{~nm}$ wavelength was calculated to be $50 \%$ (Figure S6). The high $\mathrm{O}_{2^{-}}$ evolution rates in accordance with decreasing of content of $\mathrm{Pt}^{\mathrm{II}}$ ion resulted from a larger number of $\mathrm{Co}^{\mathrm{II}}$ ions, serving as active sites. The low $\mathrm{O}_{2}$-evolution rates at low contents of $\mathrm{Pt}^{\mathrm{II}}$ ions ( 0.16 and 0 ) may result due to decreasing available space inside the crystals from increasing the unit with octahedral coordination, $\left[\mathrm{Co}^{\mathrm{III}}(\mathrm{CN})_{6}\right]^{3-}$. 
a)

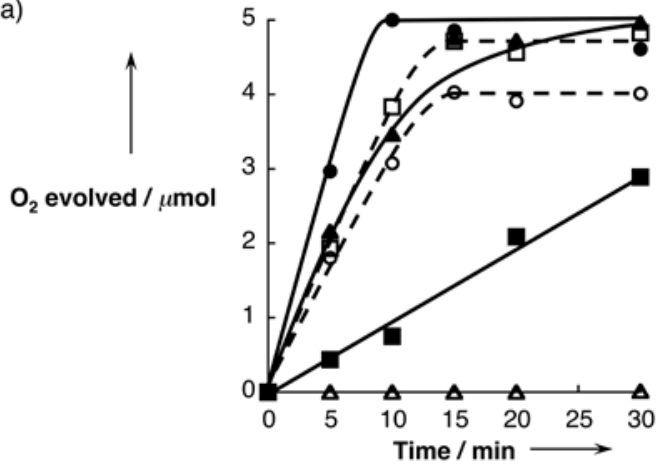

b)

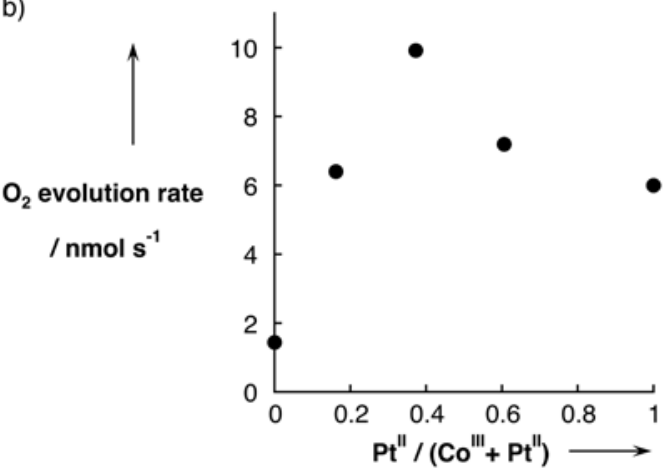

provides a convenient way to develop efficient water oxidation catalysts.

\section{Experimental Section}

Heteropolynuclear cyanide complexes were prepared by mixing an aqueous solution containing $\mathrm{K}_{3}\left[\mathrm{Co}^{\prime \prime \prime}(\mathrm{CN})_{6}\right]$ and $\mathrm{K}_{2}\left[\mathrm{Pt}^{\mathrm{IV}}(\mathrm{CN})_{6}\right]$ or $\mathrm{K}_{2}\left[\mathrm{Pt}(\mathrm{CN})_{4}\right]$ with that containing $\mathrm{Co}\left(\mathrm{NO}_{3}\right)_{2}$ to form precipitates. The contents of $\mathrm{Co}^{\mathrm{III}}$ and $\mathrm{Pt}^{\mathrm{IV}}$ ions in a prepared complex were determined by X-ray fluorescence measurements (Rigaku ZSX 1000/MPS). A typical procedure for a catalysis measurement is as follows: a heteropolynuclear cyanide complex $(80 \mu \mathrm{g})$ was suspended to a phosphate buffer $(\mathrm{pH} 8.0,50 \mathrm{mM}, 2.0 \mathrm{~mL})$ containing $\left[\mathrm{Ru}\left(2,2^{\prime} \text {-bipyridine }\right)_{3}\right] \mathrm{SO}_{4}$ $(1.0 \mathrm{mM})$ and $\mathrm{Na}_{2} \mathrm{~S}_{2} \mathrm{O}_{8}(5.0 \mathrm{mM})$ under $\mathrm{Ar}$ atmosphere. After photoirradiation $(\lambda>420 \mathrm{~nm})$ of the suspension with magnetic stirring, an aliquot of a headspace gas was analyzed to determine the amount of evolved $\mathrm{O}_{2}$ by a gas chromatograph (Shimadzu GC-17A equipped with a molecular sieve $5 \mathrm{~A}$ column and thermal conductivity detector). Repetitive reactions were conducted by addition of $\mathrm{Na}_{2} \mathrm{~S}_{2} \mathrm{O}_{8}$ to a reaction solution after ceasing $\mathrm{O}_{2}$ evolution where the $\mathrm{pH}$ of the solution was adjusted to a certain value. The experimental details about chemicals and other characterization of complexes are described in the Supporting Information.

Received: ((will be filled in by the editorial staff))

Published online on ((will be filled in by the editorial staff))

Keywords: water oxidation $\cdot$ synergistic effect $\cdot$ cobalt $\cdot$ platinum $\cdot$ cyanide complex

Figure 6. a) Time courses of $\mathrm{O}_{2}$ evolution by visible-light irradiation ( $>420 \mathrm{~nm})$ of a phosphate buffer $(2.0 \mathrm{~mL}, 50 \mathrm{mM}, \mathrm{pH}$ 8.0) containing $\left[\mathrm{Ru}(\mathrm{bpy})_{3}\right]^{2+}(1.0 \mathrm{mM}), \mathrm{Na}_{2} \mathrm{~S}_{2} \mathrm{O}_{8}(5.0 \mathrm{mM})$ and a heteropolynuclear cyanide complex, $\left[\mathrm{Co}^{\prime \prime}\left(\mathrm{H}_{2} \mathrm{O}\right)_{2}\right]_{n}\left[\left\{\mathrm{Co}^{\prime \prime \prime}(\mathrm{CN})_{6}\right\}_{1-x}\left\{\mathrm{Pt}^{\prime \prime}(\mathrm{CN})_{4}\right\}_{x}\right](80 \mu \mathrm{g}) . \mathrm{x}=0$ (closed square); 0.16 (open square); 0.37 (closed circle); 0.60 (closed triangle) and 1 (open circle). Time course of $\mathrm{O}_{2}$ evolution under dark conditions using the complex with $x=0.37$ (open triangle) b) Initial $\mathrm{O}_{2}$ evolution rates $(<5 \mathrm{~min})$ depending on the content of $\mathrm{Pt}^{\prime \prime}$ ion in $\left[\mathrm{Co}^{\prime \prime}\left(\mathrm{H}_{2} \mathrm{O}\right)_{2}\right]_{n}\left[\left\{\mathrm{Co}{ }^{\prime \prime \prime}(\mathrm{CN})_{6}\right\}_{1-x}\left\{\mathrm{Pt}^{\prime \prime}(\mathrm{CN})_{4}\right\}_{x}\right]$.

Repetitive experiments

using $\left[\mathrm{Co}^{\mathrm{II}}\left(\mathrm{H}_{2} \mathrm{O}\right)_{2}\right]_{1.31}\left[\left\{\mathrm{Co}^{\mathrm{III}}(\mathrm{CN})_{6}\right\}_{0.63}\left\{\mathrm{Pt}^{\mathrm{II}}(\mathrm{CN})_{4}\right\}_{0.37}\right](800 \mu \mathrm{g})$ as a water oxidation catalyst were performed by the same procedure as the experiments that used $\left[\mathrm{Co}^{\mathrm{II}}\left(\mathrm{H}_{2} \mathrm{O}\right)_{1.79}\right]_{1.42}\left[\left(\mathrm{Co}^{\mathrm{III}}{ }_{0.85} \mathrm{Pt}^{\mathrm{IV}}{ }_{0.15}\right)(\mathrm{CN})_{6}\right] . \mathrm{O}_{2}$ yields higher than $80 \%$ were obtained for $3^{\text {rd }}$ run (Figure S7). The XRD pattern and $v(\mathrm{CN})$ in IR spectroscopy of $\left[\mathrm{Co}^{\mathrm{II}}\left(\mathrm{H}_{2} \mathrm{O}\right)_{2}\right]_{1.31}\left[\left\{\mathrm{Co}^{\mathrm{III}}(\mathrm{CN})_{6}\right\}_{0.63}\left\{\mathrm{Pt}^{\mathrm{II}}(\mathrm{CN})_{4}\right\}_{0.37}\right]$ after the reaction were the same as those of the fresh catalyst (Figures S8 and S9). IR spectra indicated that strong adsorption of negatively charged $\mathrm{SO}_{4}{ }^{2-}$ on $\left[\mathrm{Co}^{\mathrm{II}}\left(\mathrm{H}_{2} \mathrm{O}\right)_{2}\right]_{1.31}\left[\left\{\mathrm{Co}^{\mathrm{III}}(\mathrm{CN})_{6}\right\}_{0.63}\left\{\mathrm{Pt}^{\mathrm{II}}(\mathrm{CN})_{4}\right\}_{0.37}\right]$, however, no adsorption of positively charged $\left[\mathrm{Ru}(\mathrm{bpy})_{3}\right]^{2+}$ or neutral bpy, which adsorbed on $\left[\mathrm{Co}^{\mathrm{II}}\left(\mathrm{H}_{2} \mathrm{O}\right)_{1.79}\right]_{1.42}\left[\left(\mathrm{Co}_{0.85}^{\mathrm{III}} \mathrm{Pt}^{\mathrm{IV}}{ }_{0.15}\right)(\mathrm{CN})_{6}\right]$, was confirmed. These results may reflect the nature of defect sites of each complex.

In conclusion, a nearly stoichiometric amount of $\mathrm{O}_{2}$ evolution was observed in visible-light $(\lambda>420 \mathrm{~nm})$ driven water oxidation efficiently catalyzed by heteropolynuclear cyanide complexes containing both $\mathrm{Co}$ and $\mathrm{Pt}$ ions. The addition of $\mathrm{Pt}^{\mathrm{IV}}(\mathrm{CN})_{6}{ }^{2-}$ units to Co cyanide complexes enhanced the catalysis for water oxidation by increasing the oxidation potential of N-bound $\mathrm{Co}^{\mathrm{II}}$ ions acting as active sites. When $\mathrm{Pt}^{\mathrm{II}}(\mathrm{CN})_{4}{ }^{2-}$ units are introduced to Co cyanide complexes, the hollow structure enables utilization of space inside the crystals. These results suggest that Pt ions irrespective of the valence are effective to enhance catalytic activity of Co cyanide complex by electronic and structural modifications. The strategy to utilize heteropolynuclear cyanide complexes reported in this study
[1] a) H. B. Gray, Nature Chemistry 2009, 1, 7-7; b) D. G. Nocera, Acc. Chem. Res. 2012, 45, 767-776.

[2] a) J. M. Thomas, Energy Environ. Sci. 2014, 7, 19-20; b) J. A. Herron, J. Kim, A. A. Upadhye, G. W. Huber, C. T. Maravelias, Energy Environ. Sci. 2015, 8, 126-157; c) J. R. McKone, N. S. Lewis, H. B. Gray, Chem. Mater. 2014, 26, 407-414.

[3] a) J. J. Concepcion, R. L. House, J. M. Papanikolas, T. J. Meyer, Proc Natl. Acad. Sci. U. S. A. 2012, 109, 15560-15564; b) S. Fukuzumi, Y. Yamada, ChemSusChem 2013, 6, 1834-1847; c) S. Berardi, S. Drouet, L. Francas, C. Gimbert-Surinach, M. Guttentag, C. Richmond, T. Stoll, A. Llobet, Chem. Soc. Rev. 2014, 43, 7501-7519. Environ. Sci. 2012, 5, 5592-5603; b) S. Fukuzumi, D. Hong, Y. Yamada, J. Phys. Chem. Lett. 2013, 4, 3458-3467; c) K. J. Young, L. A. Martini, R. L. Milot, R. C. Iii, V. S. Batista, C. A. Schmuttenmaer, R. H. Crabtree, G. W. Brudvig, Coord. Chem. Rev. 2012, 256, 2503-2520.

[5] a) D. G. H. Hetterscheid, L. Sun, Eur. J. Inorg. Chem. 2014, 2014, 571572; b) M. D. Kärkäs, E. V. Johnston, O. Verho, B. Åkermark, Acc. Chem Res. 2014, 47, 100-111; c) M. D. Kärkäs, O. Verho, E. V. Johnston, B. Åkermark, Chem. Rev. 2014, 114, 11863-12001; d) A. R. Parent, K. Sakai, ChemSusChem 2014, 7, 2070-2080.

[6] a) A. Harriman, I. J. Pickering, J. M. Thomas, P. A. Christensen, J. Chem. Soc., Faraday Trans. 1 1988, 84, 2795-2806; b) F. Jiao, H. Frei, Energy Environ. Sci. 2010, 3, 1018-1027.

[7] a) J. L. Boyer, J. Rochford, M.-K. Tsai, J. T. Muckerman, E. Fujita, Coord. Chem. Rev. 2010, 254, 309-330; b) J. R. Galán-Mascarós, ChemElectroChem 2015, 2, 37-50; c) M. Hirahara, A. Shoji, M. Yagi, Eur. J. Inorg. Chem. 2014, 2014, 595-606; d) X. Sala, S. Maji, R. Bofill, J. Garcia-Anton, L. Escriche, A. Llobet, Acc. Chem. Res. 2014, 47, 504-516; e) A. Singh, L. Spiccia, Coord. Chem. Rev. 2013, 257, 2607-2622; f) D. J. Wasylenko, R. D. Palmer, C. P. Berlinguette, Chem. Commun. 2013, 49, 218-227.

[8] a) J. J. Stracke, R. G. Finke, ACS Catal. 2014, 4, 909-933; b) J. D. Blakemore, N. D. Schley, G. W. Olack, C. D. Incarvito, G. W. Brudvig, R. H. Crabtree, Chem. Sci. 2011, 2, 94-98; c) D. Hong, M. Murakami, Y. Yamada, S. Fukuzumi, Energy Environ. Sci. 2012, 5, 5708-5716; d) D. Hong, J. Jung, J. Park, Y. Yamada, T. Suenobu, Y.-M. Lee, W. Nam, S. Fukuzumi, Energy Environ. Sci. 2012, 5, 7606-7616.

[9] a) M. Zhang, H. Frei, Catal. Lett. 2014, 145, 420-435; b) D. Hong, Y. Yamada, T. Nagatomi, Y. Takai, S. Fukuzumi, J. Am. Chem. Soc. 2012, 134, 19572-19575; c) Y. Yamada, K. Yano, D. Hong, S. Fukuzumi, Phys. Chem. Chem. Phys. 2012, 14, 5753-5760.

[10] a) T. Zhang, W. Lin, Chem. Soc. Rev. 2014, 43, 5982-5993; b) S. GobernaFerrón, W. Y. Hernández, B. Rodríguez-García, J. R. Galán-Mascarós, ACS Catal. 2014, 4, 1637-1641; c) S. Pintado, S. Goberna-Ferron, E. C. Escude-

[11] a) H. J. Buser, D. Schwarzenbach, W. Petter, A. Ludi, Inorg. Chem. 1977, 16, 2704-2710; b) X.-P. Shen, Y.-Z. Li, Y. Song, Z. Xu, G.-C. Guo, Eur. J. Inorg. Chem. 2007, 2007, 1698-1702.
[4] a) A. Sartorel, M. Carraro, F. M. Toma, M. Prato, M. Bonchio, Energy ro-Adan, J. R. Galan-Mascaros, J. Am. Chem. Soc. 2013, 135, 13270-13273. 
[12] Y. Yamada, M. Yoneda, S. Fukuzumi, Chem.-Eur. J. 2013, 19, 1173311741.

[13] a) J. M. Herrera, A. Bachschmidt, F. Villain, A. Bleuzen, V. Marvaud, W. Wernsdorfer, M. Verdaguer, Philos. Trans. R. Soc., A 2008, 366, 127-138; b) M. Verdaguer, G. S. Girolami, in Magnetism: molecules to materials, Vol. V (Eds.: J. S. Miller, M. Drillon), Wiley-VCH, Weinheim, 2005.
[14] R. D. Shannon, Acta Crystallogr., Sect. A: Cryst. Phys., Diffr., Theor. Gen. Crystallogr. 1969, 32, 751-767.

[15] M. R. Robin, Inorg. Chem. 1962, 1, 337-342.

[16] M. Hara, C. C. Waraksa, J. T. Lean, B. A. Lewis, T. E. Mallouk, J. Phys. Chem. A 2000, 104, 5275-5280. 


\section{Water Oxidation}

Yusuke Yamada*, Kohei Oyama, Rachel Gates, and Shunichi Fukuzumi*

$$
\text { Page - Page }
$$

Nearly stoichiometric amount of $\mathrm{O}_{2}$ evolution was observed by visible-light irradiation of an aqueous buffer $(\mathrm{pH} 8)$ containing [Ru"(2,2'-bipyridine) $)_{3}$, $\mathrm{Na}_{2} \mathrm{~S}_{2} \mathrm{O}_{8}$ and a heteropolynuclear cyanide complex containing $\mathrm{Co}$ and $\mathrm{Pt}$ ions as a photosensitizer, a sacrificial electron acceptor, and a water oxidation catalyst, respectively. Synergistic effect between Co and Pt ions was confirmed for the water oxidation catalysis of the heteropolynuclear complexes. 